\title{
Do Brand Image and Brand Trust Mediate the Effect of Service Quality on Brand Loyalty? Lessons from Higher Education Sector
}

\author{
Milcha Handayani Tammubua \\ Faculty of Economics, Universitas Terbuka, Indonesia \\ Email:milcha@ecampus.ut.ac.id
}

\begin{abstract}
:
This study analyzes the relationship between service quality on brand image, brand trust, and brand loyalty in the higher education sector. This study used a 4-point Likert scale questionnaire to collect the data from 185 students at the Distance Learning Program Unit Universitas Terbuka Jayapura registered in 2014-2018. It also employed the Structural Equation Modeling Partial Least Square (SEM-PLS) method to analyze the data with the help of SmartPLS 3 software. The results showed that service quality positively and significantly affected the brand image, brand trust, and brand loyalty. Brand trust has a positive and significant effect on brand loyalty, while the brand image has no significant effect on brand loyalty.
\end{abstract}

\section{Keywords:}

service quality; brand image; brand trust; brand loyalty

\section{Introduction}

The development and widespread use of technology has influenced the university level's educational process (Urh et al., 2015). The use of multimedia, information, and internet technology has changed the teaching and learning process, no longer confined to traditional classrooms (Zhang \& Nunamaker, 2003) and shifting to e-learning systems (Wang et al., 2007; Warokka et al., 2020). According to Sun et al. (2008), e-learning is a modern educational paradigm in which telecommunications technology conveys information for education and training.

Many universities have switched to distance learning programs, where e-learning systems are the platform or so-called online classes (Crawford et al., 2020). E-learning uses technology that allows lecturer and student interactions to be in different places (Bell et al., 2017). Online distance learning focuses on how shared spaces can communicate ideas and produce specific learning content (Alchamdani et al., 2020; Hansch et al., 2015).

Universitas Terbuka (UT) is the pioneer of distance higher education in Indonesia, followed by other competing universities such as Gadjah Mada University (UGM), University of Indonesia (UI), Bandung Institute of Technology (ITB), AMIKOM University Yogyakarta, Bina Nusantara University, and other universities. With so many universities opening distance learning programs, the market share of distance higher education has turned competitive. A competitive environment will encourage universities to use marketing ideas to differentiate themselves from competitors (Hanaysha et al., 2011; Kotler \& Fox, 1985; Maringe, 2005) and build organizational brands (Davis \& Dunn, 2002). 


\section{Britain International of Humanities and Social Sciences (BIoHS) Journal \\ ISSN: 2685-3868(Online), 2685-1989(Print) \\ Vol. 3, No. 2, June 2021, Page: 302-315}

According to Erdoğmuş and Ergun (2016), brand management in higher education is critical because of the high competition in the academic environment. A brand will reflect how the university can meet student needs, create trust in the university to provide the services needed and help prospective students make the right educational decisions (Nguyen et al., 2016; Tammubua et al., 2015). With strategic branding, universities will improve their position in the market, increase the number of students enrolling, improve university rankings, improve graduate career prospects, or get institutional support from various authorities (Erdoğmuş \& Ergun, 2016). Therefore, it is essential to manage a good university brand which ultimately leads to high brand loyalty.

Brand loyalty is a deeply held commitment by customers to repurchase or re-subscribe to products/services in the future, leading to purchasing the same brand (Oliver, 1999). Marketers use brand loyalty as a powerful and strategic weapon in offering a long-term and sustainable competitive advantage (Jones \& Kim, 2011). Brand loyalty will lead to many marketing advantages such as reduced marketing costs, gaining more new customers, setting up barriers for competitors, generating more significant revenue, and inhibiting customer vulnerability to competitors' marketing efforts (Aaker, 1991).

Besides brand loyalty, companies need to create a brand image and brand trust because empirical findings prove that these two factors play an essential role in increasing brand loyalty (Dhurup et al., 2018; Saeed et al., 2013). Consumers often use the brand image to infer product/service quality and decide their behavior (Salinas \& Pérez, 2009). Building a good brand image will help the company build its position in the market and protect the brand from other competitors (Cretu \& Brodie, 2007). If the university has a unique and positive brand image, it will affect its reputation and affect the student experience at the university (Berry, 2000). A good brand image and reputation will increase student satisfaction and ultimately result in word-of-mouth promotion and positive brand loyalty (Panda et al., 2019). Brand trust is also considered to be able to increase brand loyalty. Brand trust will reduce uncertainty in the environment, and consumers will rely only on trusted brands (Zehir et al., 2011). Brand trust can be formed if the company keeps promises to customers by providing superior performance; thus, it can guarantee customer brand loyalty (Chiou \& Droge, 2006).

Brand trust can be built by improving service quality (Caceres \& Paparoidamis, 2007). Likewise, brand image and brand loyalty can be improved through service quality (Saeed et al., 2013). In recent years, improving the service quality of educational institutions has become an important topic (Chen, 2016). Service quality is the customer's assessment of the overall service excellence (Parasuraman et al., 1988). In a competitive environment, universities must improve their services' quality continuously, thereby forming a positive brand image and reputation that leads to increased student satisfaction and loyalty (Panda et al., 2019).

Based on the description described, this study aims to determine and analyze the effect of service quality on brand image, brand trust, and brand loyalty in the higher education sector. Looking at the 33 years of experience at the Universitas Terbuka, this research tries to broaden the horizons of understanding university branding, which focuses on brand loyalty, brand image, and brand trust influenced by service quality. Sound brand management principles and strategies can be used to overcome the branding barriers of distance higher education. The results of this study are expected to provide an overview and input to university leaders in building and improving service quality, maintaining brand trust, brand image, and strong university brand loyalty and positive thoughts in the community. 


\section{Review of Literatures}

\subsection{Brand Loyalty}

Brand loyalty is a focal point that attracts researchers and marketing practitioners (Irem \& Mesut, 2012). Brand loyalty is a commitment held by customers to continuously repurchase or re-subscribe to the product/service of the chosen brand in the future, causing the purchase of the same brand (Oliver, 1999). Brand loyalty is categorized into two aspects, namely behavioral and attitude aspects. Behavioral loyalty is a repeated and consistent purchase of a product or service from a brand. In contrast, attitudinal loyalty is a psychological trait of repeat purchase intentions and buying behavior of customers who pay high prices to buy certain brands (Rizan et al., 2014).

Consumer loyalty to the brand is one source to build a competitive advantage in the service company environment (Prabantara, 2018; Rizan et al., 2020). When customers are satisfied with the goods/services provided, it increases purchases and reduces the amount of criticism given to the goods/services (Johnson et al., 2001). According to Waseem (2016), brand loyalty can be measured by the number of purchases or the frequency of purchases made by customers. The higher the purchase or the frequency shown, the higher the level of customer loyalty (Waseem, 2016).

\subsection{Brand Image}

Brand image is a customer's mental picture of an offer and includes a symbolic meaning associated with a specific attribute of a product or service (Salinas \& Pérez, 2009). According to Woisetschläger and Michaelis (2012), brand image is a consumer perception formed in the customer's memory and is reflected in brand associations. The image formed in the customer's mind depends on his knowledge and perception of the brand (Alimen \& Cerit, 2010). According to Lee et al. (2011), the brand image includes knowledge, customer opinions were given, and physical and non-physical characteristics of a brand's product. Brand image motivates consumers to buy a product or brand because of its functional attributes and benefits and the symbolic meaning associated with it (Hyun Baek \& Whitehill King, 2011; Padgett \& Allen, 1997). A good brand image is a positive manifestation for companies whose products can be accepted by consumers because they have characteristics and advantages compared to similar products from other companies (Suchanek et al in Romdonny \& Rosmadi, 2019)

\subsection{Brand Trust}

Trust is considered as one of the essential components in the relationship between sellers and buyers, and the role of customer trust increases with increasing competition (Esmaeilpour et al., 2017). Trust will be more prominent in situations of uncertainty, information asymmetry, and fear of opportunity (Lakhsmidevy et al., 2018). According to Lassoued and Hobbs (2015), trust is a positive belief given to the reliability of someone or something. Zehir et al. (2011) concluded that brand trust is the willingness of consumers to rely on the ability of a brand to do specific tasks. Customers will trust a brand if the brand can continuously satisfy customer needs or interests.

\subsection{Service Quality}

Service is defined as an action or performance provided by producers to their customers (Narotama, 2019). According to Berry et al. (1988), service quality, in general, is a global assessment or attitude related to the superiority of services provided by manufacturers. Customer ratings of service quality depend on the gap between expectations and perceptions of the actual level of performance (Parasuraman et al., 1985, 1988). According to Lovelock in 
Fortunata \& Toni (2020), service quality is the result of an evaluation process in which customers compare their perception of service and results with what they expect. Chou et al. (2011) also conclude that service quality is the difference between consumers' perceptions of the services offered by a particular company and their expectations about the companies that offer those services. Parasuraman et al. (1988) proposed that service quality can be evaluated with five primary dimensions: tangible, reliability, responsiveness, assurance, and empathy. Venter et al in Kusumadewi \& Karyono (2019) stated that Service quality in the retail becomes an important in forming image and increase sustainable competitive advantage, because competitive advantage success is driven by service quality that exceed customer expectations.

\subsection{Hypotheses Development}

\section{a. Service Quality on Brand Image, Brand Trust, and Brand Loyalty}

Companies can maintain their competitive advantage in the market if they understand the aspects of service quality expected by customers, thereby ultimately getting a good brand image compared to their competitors (Setyadi et al., 2017). Empirical findings show that the quality of a brand perceived by customers will provide value and lead customers to buy the brand (Aaker, 2012). Some researchers also found a positive and significant relationship between service quality variables and brand image (Wu et al., 2011). A positive company image will be formed when customers are satisfied with the quality of services provided (Yang et al., 2017). More specifically, Alkhawaldeh et al. (2020) found a positive effect of service quality on university brand image. Service quality is an essential factor that affects the overall brand image of the university (Panda et al., 2019). Based on previous empirical findings, the first hypothesis proposed in this study is:

H1: Service quality has a positive and significant effect on brand image.

Besides being able to affect brand image, service quality is also considered to build customer trust in a brand (Caceres \& Paparoidamis, 2007). Brand trust will be formed when customers are satisfied with the quality of services provided (Shoukat \& Zaid, 2020). When customers get the best service, customer trust will gradually emerge, assuming that customers benefit from the services provided (Prameka et al., 2017). Previous empirical findings have also proven the positive influence of service quality on brand trust (Esmaeilpour et al., 2017; Maeriyana et al., 2019). Therefore, the following hypothesis proposed in this study is:

H2: Service quality has a positive and significant effect on brand trust.

Good service quality will make customers feel satisfied to continue to buy the products offered to them (Ashraf et al., 2018). Previous empirical findings have proven a positive relationship between service quality and brand loyalty (Prabantara, 2018; Waseem, 2016). Every customer has certain expectations for a product/service, and if the company can provide services that are more than expectations, it can lead to customer loyalty to the brand (Arman \& Shabbir, 2020). Thus, the following hypothesis proposed in this study is:

H3: Service quality has a positive and significant effect on brand loyalty.

\section{b. Brand Image on Brand Loyalty}

Brand image will create consumers' cognitive, emotional, and behavioral responses as an outcome that helps the company (Padgett \& Allen, 1997). Differences in brand image in the market will make customers choose which products they will buy (Wel et al., 2011). According to Chen, 2016), the company must have a positive brand image to build long-term and mutually beneficial relationships with customers. After the brand image is firmly attached to the customer, it will make customer loyalty to the brand high. Several previous researchers have proven that brand image has a positive and significant influence on brand loyalty (Saeed et al., 2013; Tunjungsari et al., 2020). Based on the theory and empirical findings, the fourth 
hypothesis proposed in this study is:

H4: Brand image has a positive and significant effect on brand loyalty.

\section{c. Brand Trust in Brand Loyalty}

Customer trust in the brand will play an essential role in driving brand loyalty (Gommans et al., 2021). According to Ahmed et al. (2014), trust in the brand arises because the promises made by manufacturers have been successfully fulfilled, thus making customers loyal. By some researchers, brand trust is considered a critical variable that can increase customer loyalty to brands (Matzler \& Mueller, 2011; Tan et al., 2011). Empirical findings have also proven the positive and significant effect of brand trust on brand loyalty (Dhurup et al., 2018; Gozukara \& Colakoglu, 2016). Tran et al. (2020) found a positive effect of brand trust on brand loyalty in the higher education sector. Customers will tend to repurchase or recommend a product or service to others when trust has been formed (Tran et al., 2020). Therefore, referring to the previous empirical findings, the fifth hypothesis proposed is:

H5: Brand trust has a positive and significant effect on brand loyalty (Figure 1).

The five hypotheses proposed are then summarized in the following research model

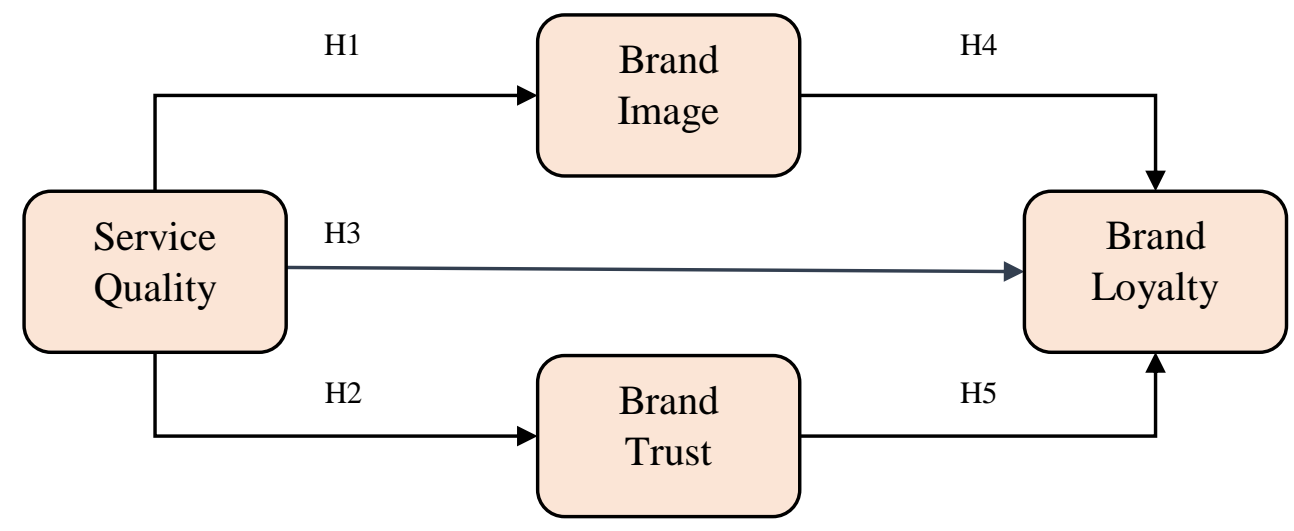

Figure 1. Research Model

\section{Research Methods}

This research data was obtained from distributing questionnaires to students of the Distance Learning Program Unit of the Universitas Terbuka at Jayapura who were registered in the 2014-2018 period. The sample is determined based on the probability sampling method. The number of samples selected was 185 respondents quoted based on the area in the Distance Learning Program Unit of the Universitas Terbuka Jayapura. The questionnaire was prepared on a 4-point Likert scale from 1, strongly disagree, to 4, strongly agree. The data analysis method used is Structural Equation Modeling Partial Least Square (SEM-PLS) with the help of SmartPLS 3 software.

\section{Discussion}

Characteristics of respondents are the identities of respondents who are used as samples in this study. Characteristics of respondents were analyzed based on gender, marital status, age, last education, occupation, and income. From the analysis of the characteristics of the respondents in Table 1, it can be concluded that the number of respondents who are students of the Distance Learning Program Unit of the Universitas Terbuka Jayapura, between men and women and are married or single, the numbers are almost equal. Then, the majority 
of respondents are in the age range of $18-25$ years $(46.50 \%)$, the last education level is high school $(75.14 \%)$, working as civil servants $(31.89 \%)$, and with an income level of 2.1-4 million rupiah $(54.10 \%)$.

Table 1. Demographic Characteristics of Respondents

\begin{tabular}{|c|c|c|c|}
\hline Category & Alternative Answer & $\begin{array}{l}\text { Number of } \\
\text { Respondents }\end{array}$ & $\begin{array}{c}\text { Percentage } \\
(\%)\end{array}$ \\
\hline \multirow{2}{*}{ Gender } & Men & 91 & 49.20 \\
\hline & Women & 94 & 50.80 \\
\hline \multirow{2}{*}{ Marital status } & Married & 90 & 48.60 \\
\hline & Single & 95 & 51.40 \\
\hline \multirow{4}{*}{ Age } & $18-25$ & 86 & 46.50 \\
\hline & $26-35$ & 65 & 35.10 \\
\hline & $36-45$ & 30 & 16.20 \\
\hline & $>46$ & 4 & 2.20 \\
\hline \multirow{3}{*}{ Last Education } & Senior High School & 139 & 75.14 \\
\hline & Diploma & 23 & 12.43 \\
\hline & Bachelor Degree & 23 & 12.43 \\
\hline \multirow{5}{*}{ Profession } & Public Officers & 59 & 31.89 \\
\hline & Private Firm Employees & 26 & 14.05 \\
\hline & Entrepreneur & 11 & 5.95 \\
\hline & Housewife & 18 & 9.73 \\
\hline & Others & 71 & 38.38 \\
\hline \multirow{4}{*}{ Income } & $<2$ million Rupiah & 53 & 28.60 \\
\hline & 2,1-4 million Rupiah & 100 & 54.10 \\
\hline & 4,1-6 million Rupiah & 24 & 13 \\
\hline & $>6$ million Rupiah & 8 & 4.30 \\
\hline
\end{tabular}

\subsection{Measurement Model}

This study applied SEM-PLS to examine the proposed research model. This study used SEM-PLS because this approach showed higher reliability than covariance-based SEM in complex research models or relatively small sample sizes (Hair et al., 2019). In evaluating the measurement model, four essential things had to do: checking factor loading, assessing the reliability of internal consistency with Composite Reliability, analyzing the convergent validity of AVE, and assessing discriminant validity (Hair et al., 2019).

Based on the results in table 2, the factor loading value of all constructs can be accepted because it is more significant than 0.6. Three items were deleted because their values were less than 0.6 (i.e., SQ4, SQ14, and BT3). Furthermore, to test the reliability of the construct, the study should check the Composite Reliability (CR) value, and the results showed that all constructions had a CR value above 0.7 , which confirms the reliability of the measurement model. Convergent validity was assessed from the Average Variance Extracted (AVE), and the results (Table 2) showed that all constructs met the minimum AVE value of 0.5. Then assess the discriminant validity using the heterotrait-monotrait correlation ratio (HTMT), where the limit value is no more than 0.9. Table 3 shows that all research variables meet discriminant validity because they have HTMT values below 0.9 (Hair et al., 2019). 
Table 2. Factor Loading and Reliability Coefficients

\begin{tabular}{|c|c|c|c|}
\hline Variable & Loading & AVE & CR \\
\hline Service Quality & & 0.502 & 0.929 \\
\hline SQ1 & 0.661 & & \\
\hline SQ2 & 0.677 & & \\
\hline SQ3 & 0.714 & & \\
\hline SQ5 & 0.687 & & \\
\hline SQ6 & 0.722 & & \\
\hline SQ7 & 0.714 & & \\
\hline SQ8 & 0.702 & & \\
\hline SQ9 & 0.716 & & \\
\hline SQ10 & 0.735 & & \\
\hline SQ11 & 0.724 & & \\
\hline SQ12 & 0.696 & & \\
\hline SQ13 & 0.702 & & \\
\hline SQ15 & 0.753 & & \\
\hline Brand Image & & 0.653 & 0.904 \\
\hline BI1 & 0.786 & & \\
\hline $\mathrm{BI} 2$ & 0.823 & & \\
\hline $\mathrm{BI} 3$ & 0.847 & & \\
\hline BI4 & 0.847 & & \\
\hline BI5 & 0.732 & & \\
\hline Brand Trust & & 0.731 & 0.915 \\
\hline BT1 & 0.849 & & \\
\hline BT2 & 0.865 & & \\
\hline BT4 & 0.892 & & \\
\hline BT5 & 0.811 & & \\
\hline Brand Loyalty & & 0.651 & 0.848 \\
\hline BL1 & 0.887 & & \\
\hline BL2 & 0.775 & & \\
\hline BL3 & 0.751 & & \\
\hline
\end{tabular}

Table 3. Heterotrait-Monotrait Ratio (HTMT)

\begin{tabular}{lcccc}
\hline & Brand Image & Brand Loyalty & Brand Trust & Service Quality \\
\hline Brand Image & & & & \\
Brand Loyalty & 0.698 & & & \\
Brand Trust & 0.807 & 0.780 & \\
Service Quality & 0.759 & 0.734 & 0.791 & \\
\hline
\end{tabular}

\subsection{Structural Model}

The R-Square value measures the variance described in each endogenous construct. R-Square values of 0.75 are considered substantial, 0.50 moderate, and 0.25 weak (Hair et al., 2011). The results of the R-Square values in table 4 show that the $\mathrm{R}$-Square values range from 0.466-0.513, which means that the explanatory model strength is sufficient (moderate). The estimated model of service quality can explain as much as $46.9 \%$ of brand image and $51.3 \%$ 
brand trust, while other variables influence the rest. Then service quality, brand image, and brand trust affect brand loyalty by $46.6 \%$, and other variables outside the studied variables influence the rest.

Table 4. R-Square Value

\begin{tabular}{lcc}
\hline & R Square & $\begin{array}{c}\text { R Square } \\
\text { Adjusted }\end{array}$ \\
\hline Brand Image & 0.469 & 0.466 \\
Brand Loyalty & 0.466 & 0.457 \\
Brand Trust & 0.513 & 0.510 \\
\hline
\end{tabular}

The test results of all hypotheses are summarized in Figure 2 and show that almost all hypotheses are accepted; only one hypothesis is rejected because the effect is not significant. The first hypothesis analysis shows that service quality positively and significantly affects the brand image, as seen from the path coefficient value of 0.685 and $\mathrm{p}$-value $<0.001$. This finding supports previous research, which found a positive and significant effect of service quality on the brand image (Alkhawaldeh et al., 2020; Wu et al., 2011). Therefore, it is essential to improve the quality of services provided to students because it will impact the university's brand image. The quality of services provided by the university to students during their education period will determine the university's brand image as a positive or negative distance higher education. If the quality of service provided is good, it will lead to a positive brand image. Otherwise, if the service quality is poor, then the brand image formed will be negative. Service quality is an essential factor that affects the overall brand image of the university (Panda et al., 2019).

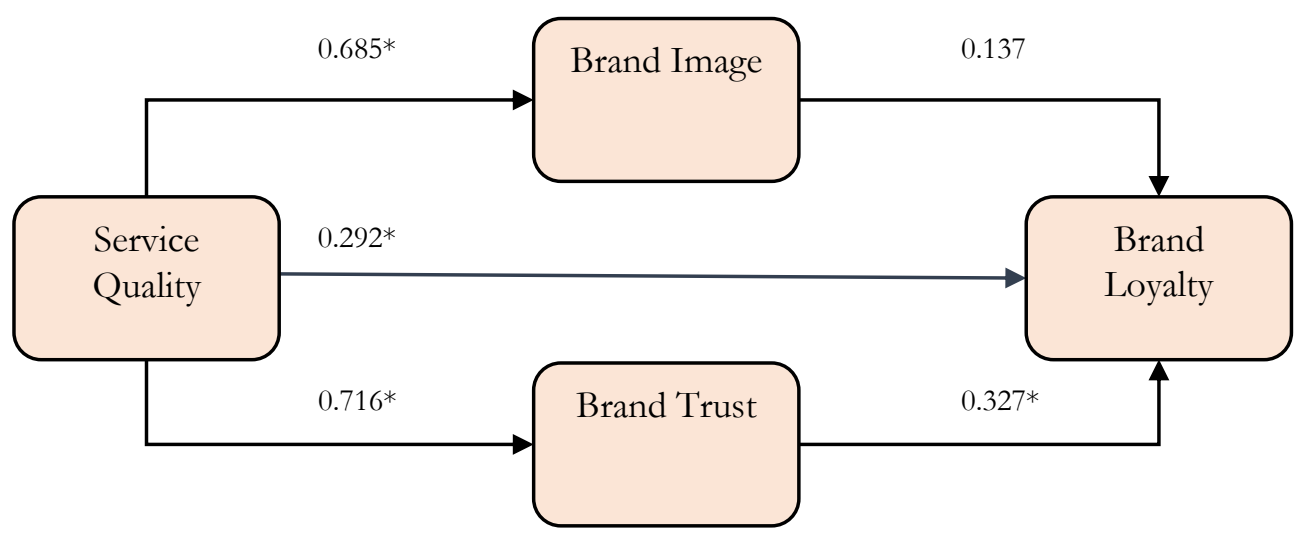

Figure 2. Hypothesis Testing Results

The results of the second hypothesis test indicate that service quality has a positive and significant effect on brand trust, as seen from the path coefficient of 0.716 and p-value $<0.001$. This finding supports the results of previous studies, which also found a positive and significant effect of service quality on brand trust (Esmaeilpour et al., 2017; Maeriyana et al., 2019). In addition to establishing the university's brand image, service quality can also build students' trust in the university's brand. If the university can consistently provide quality services, it will build student brand trust in the Universitas Terbuka as a quality and trusted distance higher education institution in Indonesia. Customer satisfaction with service quality determines customer trust in the brand (Shoukat \& Zaid, 2020). 
Furthermore, this study can also prove the third hypothesis; service quality has a positive and significant effect on brand loyalty, as seen from the path coefficient 0.292 and pvalue $<0.001$. This finding supports previous research, which also found similar results (Prabantara, 2018; Waseem, 2016). It is vital for universities to continuously improve service quality standards because it will affect student loyalty to the university brand. The better the quality of services provided by the university, students will choose the Universitas Terbuka again to take the next level of education or recommend the Universitas Terbuka to others. Hennig-Thurau et al. (2001) found that graduated students will express their loyalty to their academic institutions by continuing to provide various supports. For instance, those supports include providing financial support such as donations or research projects, promoting the institution by word of mouth to other prospective students, and offering academic collaborations such as student placements or guest lectures.

This study cannot prove the fourth hypothesis which states that brand image has a positive and significant effect on brand loyalty and cannot support previous research (Saeed et al., 2013; Tunjungsari et al., 2020). The value of the path coefficient of brand image on brand loyalty is 0.137 , and the p-value is more significant than 0.05 , which means that there is no significant effect. The brand image owned by the Open University cannot affect the level of student loyalty to the Universitas Terbuka brand. This finding can be caused by students who are more concerned with internal university factors such as the quality of services provided than the university's brand image. Thus, a good brand image does not necessarily make students loyal to the university brand.

The results of the latest hypothesis testing show that brand trust has a positive and significant effect on brand loyalty which supports the fifth hypothesis and previous studies that found similar results (Dhurup et al., 2018; Gozukara \& Colakoglu, 2016). The value of the path coefficient of brand trust on brand loyalty is 0.327 with a $\mathrm{p}$-value $<0.001$, which means that there is a positive and significant effect. The higher the student's trust in the university brand, the higher the loyalty to the brand. Therefore, universities must focus on increasing student trust to increase student loyalty to the university brand.

\section{Conclusion}

This study analyzes the relationship between service quality on brand image, brand trust, and brand loyalty. The quality of services provided by the university will have a positive effect on brand image, brand trust, and brand loyalty. Furthermore, the formed brand trust will increase student loyalty to the brand. This study cannot prove the positive influence of brand image on brand loyalty.

This study will provide an overview of marketing strategies for universities to differentiate themselves from competitors and develop a sustainable competitive advantage. The Universitas Terbuka must continuously review, evaluate, and improve the quality of services provided to students. It will form a positive brand image and increase student trust and loyalty to the brand. Universities can use the latest technology that can support distance learning to be more effective. In addition, the Universitas Terbuka continually evaluates the distance learning system provided and improves its quality to strengthen its brand image as a pioneer of quality distance higher education in Indonesia. In general, universities must also work hard to achieve student satisfaction with the services provided to give back and recommend others to their alma mater. 


\section{References}

Aaker, D. A. (1991). Managing Brand Equity: Capitalizing on the Value of a Brand Name. New York: The Free Press.

Aaker, D. A. (2012). Building Strong Brands. London: Simon \& Schuster.

Ahmed, Z., Rizwan, M., Ahmad, M., \& Haq, M. (2014). Effect of brand trust and customer satisfaction on brand loyalty in Bahawalpur. Journal of Sociological Research, 5(1), 306-326. https://doi.org/10.5296/jsr.v5i1.6568

Alchamdani, A., Fatmasari, F., Rahmadani Anugrah, E., Putri Sari, N., Putri, F., \& Astina, A. (2020). The Impact of Covid19 Pandemic on Online Learning Process in the College at Southeast Sulawesi. Jurnal Kesehatan Lingkungan, 12(1si), 129. https://doi.org/10.20473/jkl.v12i1si.2020.129-136

Alimen, N., \& Cerit, A. G. (2010). Dimensions of brand knowledge Turkish university students' consumption of international fashion brands. Journal of Enterprise Information Management, 23(4), 521-537. https://doi.org/10.1108/17410391011061799

Alkhawaldeh, A., Alsaad, A., Taamneh, A., \& Alhawamdeh, H. (2020). Examining antecedents and consequences of university brand image. Management Science Letters, 10(5), 953960. https://doi.org/10.5267/j.msl.2019.11.016

Arman, \& Shabbir, S. A. (2020). Impact of Service Quality and Brand Image on Brand Loyalty: The Mediating Role of Customer Satisfaction. Eurasian Journal of Social Sciences, 8(2), 75-84. https://doi.org/10.15604/ejss.2020.08.02.004

Ashraf, S., Ilyas, R., Imtiaz, M., \& Ahmad, S. (2018). Impact of Service Quality, Corporate Image and Perceived Value on Brand Loyalty with Presence and Absence of Customer Satisfaction: A Study of four Service Sectors of Pakistan. International Journal of Academic Research in Business and Social Sciences, 8(2). https://doi.org/10.6007/ijarbss/v8-i2/3885

Bell, S., Douce, C., Caeiro, S., Teixeira, A., Martín-Aranda, R., \& Otto, D. (2017). Sustainability and distance learning: a diverse European experience? Open Learning, 32(2), 95-102. https://doi.org/10.1080/02680513.2017.1319638

Berry, L. L. (2000). Cultivating service brand equity. Journal of the Academy of Marketing Science, 28(1), 128-137. https://doi.org/10.1177/0092070300281012

Caceres, R. C., \& Paparoidamis, N. G. (2007). Service quality, relationship satisfaction, trust, commitment and business-to-business loyalty. In European Journal of Marketing (Vol. 41, Nomor 7-8). https://doi.org/10.1108/03090560710752429

Chen, C.-T. (2016). The Investigation on Brand Image of University Education and Students' Word-of-Mouth Behavior. Higher Education Studies, 6(4), 23. https://doi.org/10.5539/hes.v6n4p23

Chiou, J. S., \& Droge, C. (2006). Service quality, trust, specific asset investment, and expertise: Direct and indirect effects in a satisfaction-loyalty framework. Journal of the Academy of Marketing Science, 34(4), 613-627. https://doi.org/10.1177/0092070306286934

Chou, C. C., Liu, L. J., Huang, S. F., Yih, J. M., \& Han, T. C. (2011). An evaluation of airline service quality using the fuzzy weighted SERVQUAL method. Applied Soft Computing Journal, 11(2), 2117-2128. https://doi.org/10.1016/j.asoc.2010.07.010

Crawford, J. \, Butler-henderson, K., Rudolph, J., Malkawi, B., Glowatz, M., Magni, P. A., \& Lam, S. (2020). COVID-19: 20 countries' higher education intra-period digital pedagogy responses. Journal of Applied Learning \& Teaching, 3(1). https://doi.org/10.37074/jalt.2020.3.1.7

Cretu, A. E., \& Brodie, R. J. (2007). The influence of brand image and company reputation where manufacturers market to small firms: A customer value perspective. Industrial 
Marketing

Management,

$36(2)$,

$230-240$.

https://doi.org/10.1016/j.indmarman.2005.08.013

Davis, S. M., \& Dunn, M. (2002). Building the brand-driven business: operationalize your brand to drive profitable growth. San Francisco, CA: Jossey-Bass.

Dhurup, M., Van Schalkwyk, P., \& Tsautse, V. J. (2018). The Relationship Between Brand Identification, Brand Trust, Brand Commitment and Brand Loyalty: Evidence From Supermarket Store Food Brands. International Journal of Business and Management Studies, 10(2), 166-182.

Erdoğmuş, İ., \& Ergun, S. (2016). Understanding University Brand Loyalty: The Mediating Role of Attitudes towards the Department and University. Procedia - Social and Behavioral Sciences, 229, 141-150. https://doi.org/10.1016/j.sbspro.2016.07.123

Esmaeilpour, M., Sayadi, A., \& Mirzaei, M. (2017). Investigating the Impact of Service Quality Dimensions on Reputation and Brand Trust. Internastional Journal of Business and Economic Science Applied Research, 10(3), 7-17.

Fortunata, R., Toni, N. (2020). The Influence of Service Quality, Tuition Fee and Promotion on Student Decisions to Continue Study in Postgraduate of Prima Indonesia University. Budapest International Research and Critics Institute-Journal (BIRCIJournal) Vol 3, No 2, Page: 829-837

Gommans, M., Krishnan, K. S., \& Scheffold, K. B. (2021). From Brand Loyalty to E-Loyalty: A Conceptual Framework. Encyclopedia of Autism Spectrum Disorders, 3(1), 42514255. https://doi.org/10.1007/978-3-319-91280-6_1200

Gozukara, I., \& Colakoglu, N. (2016). A Research on Generation Y Students: \r $\backslash n$ Brand Innovation, Brand Trust and Brand Loyalty. International Journal of Business Management and Economic Research, 7(2), 603-611.

Hair, Joe F, Ringle, C. M., \& Sarstedt, M. (2011). PLS-SEM: Indeed a Silver Bullet. Journal of Marketing Theory and Practice, 19(2), 139-152. https://doi.org/10.2753/MTP10696679190202

Hair, Joseph F, Risher, J. J., Sarstedt, M., \& Ringle, C. M. (2019). When to use and how to report the results of PLS-SEM. European Business Review, 31(1), 2-24. https://doi.org/10.1108/EBR-11-2018-0203

Hanaysha, J. R., Abdullah, H. H., \& Warokka, A. (2011). Service quality and students' satisfaction at higher learning institutions: The competing dimensions of Malaysian universities' competitiveness. The Journal of Southeast Asian Research, 2011, 1-10. Article ID 855931. DOI: 10.5171/2011.855931

Hansch, A., Hillers, L., McConachie, K., Newman, C., Schildhauer, T., \& Schmidt, P. (2015). Video and Online Learning: Critical Reflections and Findings from the Field. SSRN Electronic Journal. https://doi.org/10.2139/ssrn.2577882

Hennig-Thurau, T., Langer, M. F., \& Hansen, U. (2001). Modeling and Managing Student Loyalty: An Approach Based on the Concept of Relationship Quality. Journal of Service Research, 3(4), 331-344. https://doi.org/10.1177/109467050134006

Hyun Baek, T., \& Whitehill King, K. (2011). Exploring the consequences of brand credibility in services. Journal of Services Marketing, 25(4), 260-272. https://doi.org/10.1108/08876041111143096

Irem, E. E., \& Mesut, C. (2012). The impact of social media marketing on brand loyalty. Social and Behavioral Sciences, 58(2), 1353-1360.

Johnson, M. D., Gustafsson, A., Andreassem, T. W., Lervik, L., \& Cha, J. (2001). The Evolution and Future of National Customer Satisfaction Index Models. Journal of Economic Psychology, 22(2), 217-245.

Jones, R., \& Kim, Y.-K. (2011). Single-brand retailers: Building brand loyalty in the off-line environment. Journal of Retailing and Consumer Services, 18(4), 333-340. https://doi.org/10.1016/j.jretconser.2011.02.007 
Kotler, P., \& Fox, K. A. (1985). Strategic marketing for educational institutions. New Jersey: Prentice-Hall.

Kusumadewi, R. N., Karyono, O. (2019). Impact of Service Quality and Service Innovations on Competitive Advantage in Retailing. Budapest International Research and Critics Institute-Journal (BIRCI-Journal) Vol 2, No 2, Page: 366-374

Lakhsmidevy, D. A. A., Rizan, M., \& Warokka, A. (2018). Pengaruh Service Quality, Customer Satisfaction, dan Brand Trust di Mediasi Oleh Customer Commitment Terhadap Customer Loyalty Penumpang Maskapai Low Cost Carrier Di Bali [The effect of service quality, customer satisfaction, and brand trust on customer loyalty: A test of customer commitment as the mediating variable]. JURNAL DINAMIKA MANAJEMEN DAN BISNIS, 1(2), 1-8. https://doi.org/10.21009/JDMB.01.2.03

Lassoued, R., \& Hobbs, J. E. (2015). Consumer confidence in credence attributes: The role of brand trust. Food Policy, 52, 99-107. https://doi.org/10.1016/j.foodpol.2014.12.003

Lee, H. M., Lee, C. C., \& Wu, C. C. (2011). Brand image strategy affects brand equity after M\&A. European Journal of Marketing, 45(7), 1091-1111. https://doi.org/10.1108/03090561111137624

Maeriyana, Soesilowati, E., \& Rozi, F. (2019). The Influence of Service Quality on Loyalty With Satisfaction, Trust and Corporate Image As Intervening Variables in Rukun Tani Village Cooperative Unit in Pageruyung District Kendal Regency. Journal of Economic Education, 8(1), 30-38.

Maringe, F. (2005). Interrogating the crisis in higher education marketing: the CORD model. International Journal of Educational Management, 19(7), 564-578. https://doi.org/10.1108/09513540510625608

Matzler, K., \& Mueller, J. (2011). Antecedents of knowledge sharing - Examining the influence of learning and performance orientation. Journal of Economic Psychology, 32(3), 317329. https://doi.org/10.1016/j.joep.2010.12.006

Narotama, A. (2019). The Effect of Service Quality on Customer Loyalty with Brand Images and Customer Satisfaction as Mediation. Jurnal Manajemen Dan Kewirausahaan, 7(1), 86-93. https://doi.org/10.26905/jmdk.v7i1.2692

Nguyen, B., Yu, X., Melewar, T. C., \& Hemsley-Brown, J. (2016). Brand ambidexterity and commitment in higher education: An exploratory study. Journal of Business Research, 69(8), 3105-3112. https://doi.org/10.1016/j.jbusres.2016.01.026

Oliver, R. L. (1999). Whence Consumer Loyalty? Journal of Marketing, 63(4_suppl1), 33-44. https://doi.org/10.1177/00222429990634s105

Padgett, D., \& Allen, D. (1997). Communicating experiences: A narrative approach to creating service brand image. Journal of Advertising, 26(4), 49-62. https://doi.org/10.1080/00913367.1997.10673535

Panda, S., Pandey, S. C., Bennett, A., \& Tian, X. (2019). University brand image as competitive advantage: a two-country study. International Journal of Educational Management, 33(2), 234-251. https://doi.org/10.1108/IJEM-12-2017-0374

Parasuraman, A., Zeithaml, V. A., \& Berry, L. L. (1985). A Conceptual Model of Service Quality and Its Implications for Future Research. Journal of Marketing, 49(4), 41-50. https://doi.org/10.1177/002224298504900403

Parasuraman, A., Zeithaml, V. A., \& Berry, L. L. (1988). SERVQUAL: A multiple-item scale for measuring consumer perceptions of service quality. Journal of retailing, 64(1), 12 40.

Prabantara, D. M. (2018). The Effect of Brand Image and Service Quality on Customer Loyalty through Customer Satisfaction as intervening variable in Pandanaran University, Semarang. Russian Journal of Agricultural and Socio-Economic Sciences, 79(7), 261-269. 
Prameka, A. S., Do, B.-R., \& Rofiq, A. (2017). How brand trust is influenced by perceived value and service quality: mediated by hotel customer satisfaction. APMBA (Asia Pacific Management and Business Application), 5(2), 73-88. https://doi.org/10.21776/ub.apmba.2016.005.02.2

Rizan, M., Warokka, A., \& Listyawati, D. (2014). Relationship marketing and customer loyalty: do customer satisfaction and customer trust really serve as intervening variables?. Journal of Marketing Research \& Case Studies, 2014, 1-12. Article ID 724178. DOI: $10.5171 / 2014.724178$

Rizan, M., Warokka, A., Wibowo, A., \& Febrilia, I. (2020). Leadership Styles and Customer Loyalty: A Lesson from Emerging Southeast Asia's Airlines Industry. The Journal of Asian Finance, Economics, and Business, 7(9), 477-488. https://doi.org/10.13106/jafeb.2020.vol7.no9.477

Romdonny, J., Rosmadi, M. L. N. (2019). Factors Affecting Customer Loyalty in Products. Budapest International Research and Critics Institute-Journal (BIRCI-Journal) Vol 2, No 1, Page: 337-343

Saeed, R., Lodhi, R. N., Mehmood, A., Ishfaque, U., Dustgeer, F., Sami, A., Mahmood, Z., \& Ahmad, M. (2013). Effect of brand image on brand loyalty and role of customer satisfaction in it. World Applied Sciences Journal, 26(10), 1364-1370. https://doi.org/10.5829/idosi.wasj.2013.26.10.1343

Salinas, E. M., \& Pérez, J. M. P. (2009). Modeling the brand extensions' influence on brand image. Journal of Business Research, 62(1), 50-60. https://doi.org/10.1016/j.jbusres.2008.01.006

Setyadi, A., Ali, H., \& Imaroh, S. (2017). Credit Risk Management: Implications on Bank Performance and Lending Growth. Saudi Journal of Business and Management Studies, 2(B), 770-777. https://doi.org/10.21276/sjbms

Shoukat, A., \& Zaid, M. (2020). Service Quality and Brand Loyalty in the Schooling Industry of Pakistan. Humanities and Social Sciences Letters, 8(2), 240-251. https://doi.org/10.18488/journal.73.2020.82.240.251

Sun, P.-C., Tsai, R. J., Finger, G., Chen, Y.-Y., \& Yeh, D. (2008). What drives a successful eLearning? An empirical investigation of the critical factors influencing learner satisfaction. Computers \& Education, 50(4), 1183-1202. https://doi.org/10.1016/j.compedu.2006.11.007

Tammubua, M. H., Febrilia, I., \& Warokka, A. (2015). Testing the competing entrepreneurial intention's antecedents on public university students. Journal of Entrepreneurship: Research \& Practice, Articles ID 251294, 1-11. DOI: 10.5171/2015.251294

Tan, T. M., Ismail, H. Bin, \& Rasiah, D. (2011). Hierarchical Chain Of Consumer-Based Brand Equity: Review From The Fast Food Industry. International Business \& $\begin{array}{llll}\text { Economics Research Journal } & \text { (IBER), }\end{array}$ https://doi.org/10.19030/iber.v10i9.5628

Tran, K., Nguyen, P., Do, H., \& Nguyen, L. (2020). University students' insight on brand equity. Management Science Letters, 10(9), 2053-2062. https://doi.org/10.5267/j.msl.2020.2.006

Tunjungsari, H. K., Syahrivar, J., \& Chairy, C. (2020). Brand loyalty as mediator of brand image-repurchase intention relationship of premium-priced, high-tech product in Indonesia. Jurnal Manajemen Maranatha, 20(1), 21-30. https://doi.org/10.28932/jmm.v20i1.2815

Urh, M., Vukovic, G., Jereb, E., \& Pintar, R. (2015). The Model for Introduction of Gamification into E-learning in Higher Education. Procedia - Social and Behavioral Sciences, 197, 388-397. https://doi.org/10.1016/j.sbspro.2015.07.154 
Wang, Y.-S., Wang, H.-Y., \& Shee, D. Y. (2007). Measuring e-learning systems success in an organizational context: Scale development and validation. Computers in Human Behavior, 23(4), 1792-1808. https://doi.org/10.1016/j.chb.2005.10.006

Warokka, A., Sjahruddin, H., Sriyanto, S., Noerhartati, E., \& Saddhono, K. (2020). Digital marketing support and business development using online marketing tools: An experimental analysis. International Journal of Psychosocial Rehabilitation, 24(1), 1181-1188. https://doi.org/10.37200/IJPR/V24I1/PR200219

Waseem, M. (2016). The Impact of Service Quality On Brand Loyalty; A Descriptive Study Of Smartphone Users In Higher Educational Institutions Of District Vehari, Punjab, Pakistan. Global Advanced Research Journal of Management and Business Studies, 5(1), 26-30.

Wel, C. A. B. C., Alam, S. S., \& Nor, S. M. (2011). Factors affecting brand loyalty: An empirical study in Malaysia. Australian Journal of Basic and Applied Sciences, 5(12), 777-783.

Woisetschläger, D. M., \& Michaelis, M. (2012). Sponsorship congruence and brand image: A pre-post event analysis. European Journal of Marketing, 46(3-4), 509-523. https://doi.org/10.1108/03090561211202585

Wu, P. C. S., Yeh, G. Y. Y., \& Hsiao, C. R. (2011). The effect of store image and service quality on brand image and purchase intention for private label brands. Australasian Marketing Journal, 19(1), 30-39. https://doi.org/10.1016/j.ausmj.2010.11.001

Yang, K. F., Yang, H. W., Chang, W. Y., \& Chien, H. K. (2017). The effect of service quality among customer satisfaction, brand loyalty and brand image. 2017 IEEE international conference on industrial engineering and engineering management (IEEM), 22862290 .

Zehir, C., Şahin, A., Kitapçi, H., \& Özçahin, M. (2011). The effects of brand communication and service quality in building brand loyalty through brand trust; the empirical research on global brands. Procedia - Social and Behavioral Sciences, 24, 1218-1231. https://doi.org/10.1016/j.sbspro.2011.09.142

Zhang, D., \& Nunamaker, J. F. (2003). Powering E-Learning In the New Millennium: An Overview of E-Learning and Enabling Technology. Information Systems Frontiers, 5(2), 207-218. https://doi.org/10.1023/A:1022609809036. 